10.2478/v10103-009-0011-x

\title{
Air transport liberalisation in the European Union and its impact on development of the civil aviation sector in Poland
}

\begin{abstract}
The objective of this paper is to present an overview of the process of air transport liberalisation within the European Community and its influence on development of the aviation market in Poland. The paper describes the stages of air transport liberalisation in the European Community and its implementation to the Polish market. The special focus is given to problems of existing effects of air transport liberalisation and perspectives of its development. The study primarily intends to examine market structure changes of the Polish civil aviation sector and air traffic dynamics over the years of Polish integration with the European Union, presenting the most up-to-date available statistics.
\end{abstract}

\section{Introduction}

European air transport network before the liberalisation process was fragmented, with airlines being treated as public entities to serve national interests. The creation of a single air transport market in the European Union made substantial benefits for customers and improved the competitiveness of the European Union air transport industry (Button 2001, pp.255-256). Implementing the transparent, common and obligatory air transport law in all of the Member States in the European Union was imposed by the necessity of free, fair and undisturbed competition on the market of air transport services. The aim of the liberalisation was to remove barriers from air transport market - to deregulate fares and make market entry independent of national frontiers. The main issue was carrier's access to market, licenses, setting tariffs and scheduling time of 
operations in airports as well as access to ground handling service and rules of using computerized reservation systems (Szymajda 2002, p.86).

Before adopting the European Union rules polish air transport market was largely state-regulated. Domestic connections were provided only by Polish carriers, whereas international flights by Polish regular airline or the second country's national carriers, accordingly to strictly defined rules of bilateral government agreements. Since 2003 due to agreement with European Union Poland has implemented liberalisation of transport market shared by Poland and the European Union Member States and Candidate Countries. Polish passengers were able to expect lower prices, wider choice of destinations and improvement of passenger rights. Most significant changes began with the EU accession on $1^{\text {st }}$ May 2004.

\section{Air transport liberalisation process within the European Community}

Commercial aviation in the European Community was regulated by a system based on bilateral negotiations until the late 1980s. Regulation ensured that airlines did not compete on protected and fragmented aviation markets. The lack of competition conflicted with the aim of the Treaty of Rome of having a common economic market. According to article 49 of the Treaty establishing the European Community "restrictions on freedom to provide services within the Community shall be prohibited"15. The regulatory system which governed aviation within the European Community had, by 1993, been replaced by a Single Market for aviation (Rocka, Weyna 2006, pp.6-7).

The opening of the European air transport sector was implemented in four main stages, the so-called "air packages" by regulating rules of competition, access to the market, procedure of setting prices and recognizing air carriers licenses, in order to create a single market for aviation (European Commission 2005, Annual... pp. 150-151).

The first "package" of measures adopted in December 1987 started to relax the established rules as well as the scope for intervention by national governments. For intra-EU traffic, it limited the right of governments to object to the introduction of new fares. It gave some flexibility to airlines concerning

\footnotetext{
${ }^{15}$ Consolidated Version of the Treaty Establishing the European Community, Official Journal of the European Communities, p.54, available online at website http://eur-lex.europa.eu/en/treaties/dat/12002E/pdf/12002E_EN.pdf.
} 
seat capacity sharing. It introduced also application of Commission competition rules to the aviation sector.

The second "package" in 1990 provided a further opening of the market, allowing greater flexibility over the setting of fares and capacity-sharing. It also gave all EU carriers the right to carry an unlimited number of passengers or cargo between their home country and another EU country. It extended the right to the fifth freedom and opened up the third and fourth freedoms to all Community carriers in general ${ }^{16}$.

The third "package" of measures applied from January 1993. This package introduced the freedom to provide services within the European Union, giving almost entire freedom of tarrifs for both cargo and scheduled flights. It regulated also the basis for flag carriers privatization, stated that their shares in majority have to be owned ny European Union citizens.

The "third package" was the most significant one including three legislative measures:

- the introduction of harmonised requirements for an operating licence for EU airlines (Council Regulation (EEC) No 2407/92),

- the open access for all EU airlines with such an operating licence to all routes within the EU (Regulation (EEC) No 2408/92). At the same time, national governments have the possibility to impose public service obligations on routes which are essential for the regional development,

- the full freedom with regard to fares and rates was also introduced (Regulation (EEC) No 2409/92). Airlines are no longer required to submit their fares to the national authorities for approval ${ }^{17}$.

The fourth "package" applied in April 1997 added the freedom to provide "cabotage": the right for an airline of one Member State to operate a route within another Member State. This single market has been extended to Norway, Iceland and Switzerland in the following years and in the medium term to the six Central-European countries.

During the 15 years of application of the "third package", the aviation market has evolved. Therefore, in July 2006, the European Commission made a proposal to modernise and simplify the legal framework for the internal air transport market. It consolidates the three existing regulations of the "third package" into one and aims to ensure an even more effective aviation market in

\footnotetext{
${ }^{16} 3^{\text {rd }}$ freedom: Right to set down traffic from home state; $4^{\text {th }}$ Freedom: Right to pick up traffic bound for home state; $5^{\text {th }}$ freedom: Right to pick up and put down traffic between two foreign states as an extension of routes to/from home state. Definition coming from Page 2005, p. 206.

${ }^{17} \mathrm{http}: / /$ ec.europa.eu/transport/air/internal_market/integration_history_en.htm.
} 
the future. This is a first stage towards the further consolidation of legislation. Studies are on-going in view of elaborating a fully fledged European Civil Aviation Code.

In consequence of liberalisation process every carrier having license to offer air transport services of passengers, issued by any of the Member State can fly on any route and offer any price of the service within rules of free, fair and undisturbed competition. The situation and new conditions of competition enforced airlines to restructure, to introduce more flexibility in price setting and flight destinations. In addition, all above mentioned regulations contributed to establishment of a new type of air carriers, so called "no-frills" or "low cost" carriers. There are several differences distinguishing "no-frills" airlines from flag carriers. Low cost carriers simplified business design providing: one kind of aircraft and one class of passengers, no free food and newspapers on board, no airport lounges, no frequent-flyer programs, no connecting flights, no possibility of rebooking to another airline and no refunds, no expensive computer reservation systems and travel agents, electronic tickets only from the beginning of their operating on the market, service from secondary airports due to lower landing and ground-handling fees. Such restrictions enabled to minimize cost and allowed setting lower fares. The number of airlines has risen, what contributed to increase in amount of traffic. As a result the competition on routes is much stronger in the sector and consumers benefited from lower prices and bigger supply of services.

The impact of liberalisation in terms of new entry and development of competition on many of the denser routes within Europe has been constrained by the lack of capacity at key airports. While existing aviation infrastructure has shown considerable ability to handle increased demand, scope for further expansion within the existing infrastructure at certain airports is strictly limited. Estimates are that air traffic will grow by $4 \%$ a year over the next years, leading to a nearby doubling of traffic by 2020. The Single European Sky is an ambitious initiative to reform the architecture of European air traffic control to meet future capacity and safety need by organising airspace and air navigation at a European rather than at a local level (European Commission 2004, The Single..., pp.4-11).

In open markets, it is important to ensure fair competition. Therefore, the European Commission applies the competition rules on mergers and alliances, price-fixing and other arrangements to the air transport sector. Furthermore, a strict enforcement of state aid rules does ensure that airlines operate in a level playing field. Moreover, European Union transport legislation is composed of rules in several subject areas as: economic policy, air traffic management, safety, 
security, environmental matters, social matters, passenger protection, external relations (European Commission 2007, Guide..., pp.1-2).

The above mentioned packages smoothed the way for a nowadays highly competitive market. Liberalisation gave a low basement for launching into the market and developing Low Cost Carrier's service in Europe. Beyond market opening, the single market rests on stringent common rules in order to both ensure a level playing field and continuously improve standards, notably in safety and security, considering also environmental matters.

\section{Implementing of air transport liberalisation rules into the polish market}

Poland's accession to the European Union was connected with obligation to adopt European legislation at a national level. Our country had to be prepared to ensure the extension of the Single Market and to guarantee the free movement of persons, goods, services and capital. In December 2000 negotiators from Poland and European Commission reached an agreement on liberalization of transport market to be implemented within three years by Poland, European Union Member States and Candidate Countries. In February 2003, the agreement on common European airspace began to be obligatory for Poland as a Candidate Country. Considering transport, the implementation of the rules required the establishment of a common transport market with free access to transport infrastructure. Every airline from each of the states-signatories was able to launch any connection not only to Poland, but also inside the Country.

Before 2003 the Polish air market was dominated by the flag carrier - LOT Polish Airlines and its market share accounted for more that $60 \%$. Implementing of new regulations contributed to low cost airlines (LCC) entrance into the Polish air transport market. The era of dynamic development of LCC in Poland began in December 2003 when Air Polonia launched its services between Warsaw and London Stansted (Rocka, Weyna 2006, pp.6-10).

LCC are more willing than flag carriers to operate at regional airports due to low airport services fares and better operational efficiencies. Launching low cost airlines into the polish market in consequence contributed to development of regional airports. Enlarged infrastructure enabled traffic growth on the polish civil aviation market.

LCC have generated new demand rather than overtaken passengers from legacy carriers making air transport services available to the new groups of passengers. Young and well-educated people, tourist searching for opportunities to visit new European countries and sometimes non-European countries are 
usually their customers. Prior to liberalization air transport was considered to be a luxurious way of traveling, unavailable for the majority of the polish society. When LCC did not provide the service the passengers used to travel by bus or train. Many LCC passengers in Poland never traveled by air before, and certainly most of them would not decide to fly if the price would not be so low. Price of low cost airline's ticket is much lower than an offer of flag airlines and rather comparable to bus or train fee. Moreover, the development of regional airports with LCC service caused advantage of shorter distance to the airport for many customers, what additionally saved their time and money.

\section{Development of the polish civil aviation sector in context of membership in the European Union}

Polish air transport market was underdeveloped before the EU accession with high potential of growth. Poland, located in the centre of European continent with 38 millions of citizens, was considered as a very attractive and promising market for air carriers. Growth of GDP per capita enabled higher expenditures of customers on air transport. Free movement of persons within the European Union intensified demand on air travel, for different purposes: traveling, working abroad, business trips.

International Air Transport Association appreciated the potential of polish air transport market in "IATA Passenger Forecast 2005-2009". Poland was expected to have the highest average annual passenger growth rate in the world. According to IATA air traffic in Poland should rise by $11,2 \%$ a year, whereas an overall industry average annual growth rate was expected to be 5,6\% and within Europe $5,1 \%{ }^{18}$.

Before accession of Poland to the European Union Polish air market was dominated by the flag carrier LOT Polish Airlines, which market share was more than $60 \%{ }^{19}$. Most of the flights were operated by flag carriers from hub airport in Warsaw. Passengers' choice was limited mainly to fly with LOT or another major European flag carrier via Warsaw Airport. Regional airports in Poland and their potential until 2004 were not enough appreciated.

LCC contributed to development of regional airports. In December 2003 Air Polonia as the first polish low cost airline launched its service between Warsaw and London Stansted, offering also domestic flights from Gdansk and

\footnotetext{
${ }^{18}$ Available at: www.iata.org.

${ }^{19}$ According to LOT Annual Reports, available at: www.lot.pl
} 
Wroclaw to Warsaw. For the summer season Air Polonia offered many destinations in Europe, e.g. Rome, Paris, Frankfurt, Athens, Brussels, Madrid and chartered flights to the Mediterranean countries. With the polish accession to the European Union new low cost airlines entered into the polish market, e.g. Germanwings, Hungarian Wizzair and Slovakian Skyeurope, operated at the beginning from Warsaw and Katowice mainly to most popular Western Countries destinations and to their capitals: Budapest and Bratislava respectively. Wizzair from very beginning established a base in Katowice and successively also in Warsaw and Gdansk. Skyeurope concentrated on creating a base in Krakow and strengthen its position in the southern Poland. Easyjet entered polish market launching flights from Warsaw and Krakow. The most dynamic and risky strategy presented Irish Ryanair in October 2005 deciding to enter eight polish airports except Warsaw at a time with daily flights to London Stansted and successively adding new destinations. LOT introduced also its low-cost subsidiary called Centralwings which launched its service in February 2005, targeting its flights at Poles working abroad, with destinations like London, Dublin, Edinburgh and offering new routs i.e. Lisbona, Bologna and charter flights to Greece, Spain and Italy (Rocka, Weyna 2006, pp.9-12).

In year 2008 there were 13 low cost airlines operating on the Polish market: Aer Lingus, Blue 1, Centralwings, Clickair, Easyjet, Germanwings, Jet 2, Norwegian Air Shuttle, Ryanair, Skyeurope, Sterling, Wizzair, Volare. There were certainly also national flag carriers offering their service in Poland, e.g. Lufthansa Deutsche Airlines, British Airways, Scandinavian Airline System, Royal Dutsch Airlines (KLM), Air France, Alitalia, Austrian Airlines etc. 
Table 1. Number of passengers served in regular traffic at all polish airports by 10 major airlines and market shares in year 2004

\begin{tabular}{|l|l|c|c|}
\hline & Airline / Year 2004 & Number of passengers (in 1000) & Market share \\
\hline 1 & LOT & 4383 & $57,86 \%$ \\
\hline 2 & LUFTHANSA & 491,9 & $6,49 \%$ \\
\hline 3 & WIZZAIR & 352 & $4,65 \%$ \\
\hline 4 & BRITISH AIRWAYS & 275,6 & $3,64 \%$ \\
\hline 5 & SAS & 270,4 & $3,57 \%$ \\
\hline 6 & KLM & 197,5 & $2,61 \%$ \\
\hline 7 & AIR FRANCE & 173,7 & $2,29 \%$ \\
\hline 8 & ALITALIA & 135,2 & $1,79 \%$ \\
\hline 9 & SKY EUROPE & 115,6 & $1,53 \%$ \\
\hline 10 & AUSTRIAN AIRLINES & 107 & $\mathbf{8 5 , 8 4 \%}$ \\
\hline & TOTAL & $\mathbf{6 5 0 1 , 9}$ & \\
\hline
\end{tabular}

Source: ULC data and own calculations. 
Table 2. Number of passengers served in regular traffic at all polish airports by 10 major airlines and market shares in year 2008

\begin{tabular}{|l|l|c|c|}
\hline & Airline / Year 2008 & Number of passengers (in 1000) & Market share \\
\hline 1 & LOT & 4999,9 & $28,03 \%$ \\
\hline 2 & WIZZAIR & 3431,6 & $19,24 \%$ \\
\hline 3 & RYANAIR & 2884,8 & $16,17 \%$ \\
\hline 4 & LUFTHANSA & 1082,5 & $6,07 \%$ \\
\hline 5 & EASYJET & 949,7 & $5,32 \%$ \\
\hline 6 & CENTRALWINGS & 706,9 & $3,96 \%$ \\
\hline 7 & NORWEGIAN & 671,9 & $3,77 \%$ \\
\hline 8 & BRITISH AIRWAYS & 292,5 & $1,64 \%$ \\
\hline 9 & SAS & 284,6 & $1,60 \%$ \\
\hline 10 & AIR FRANCE & 260,8 & $\mathbf{8 7 , 2 6 \%}$ \\
\hline & TOTAL & $\mathbf{1 5 5 6 5 , 2}$ & \\
\hline
\end{tabular}

Source: ULC data and own calculations.

It can be assumed that Polish passenger air transport market in highly concentrated. Market share of ten top airlines operating on the Polish marked increased from $85,8 \%$ in year 2004 to more than $87 \%$ in year 2008 . Three the most significant airlines served in year 2004 exactly $69 \%$ of passengers and in year 2008 there was a decrease to $63,4 \%$.

Mobility of the structure was significant. In year 2004 among ten the most important airlines on the Polish market there were only two low cost airlines with summary market share of $6,18 \%$, whereas in year 2008 there were already five no-frills carriers in the table with more than $48 \%$ of passengers served.

Number of passengers served in 2008 by ten major airlines increased in comparison with year 2004 by almost $140 \%$ to more than 15,5 millions of customers. Flag carriers were loosing their market shares between 2004 and 2008 , but not a traffic volume, which was increasing. LOT was loosing its 
market share, as well, what is presented in the table below. Position of low cost carriers on the Polish market has improved rapidly between 2004 and 2008.

Table 3. Number of passengers and market share of LOT Polish Airlines and all low cost carriers (LCC) operating on the Polish market in years 2004 - 2008

\begin{tabular}{|l|c|c|c|c|c|}
\hline Year & $\mathbf{2 0 0 4}$ & $\mathbf{2 0 0 5}$ & $\mathbf{2 0 0 6}$ & $\mathbf{2 0 0 7}$ & $\mathbf{2 0 0 8}$ \\
\hline $\begin{array}{l}\text { LOT - passengers served } \\
\text { (in thousand) }\end{array}$ & 4383 & 4517,4 & 4715,2 & 5427,4 & 4999,9 \\
\hline LOT - market share & $57,9 \%$ & $43,8 \%$ & $33,6 \%$ & $31,5 \%$ & $28,0 \%$ \\
\hline $\begin{array}{l}\text { LCC - passengers served } \\
\text { (in thousand) }\end{array}$ & 984,7 & 3230,2 & 6517,7 & 8618,5 & 9386,4 \\
\hline LCC - market share & $13,0 \%$ & $31,3 \%$ & $46,4 \%$ & $50,1 \%$ & $52,6 \%$ \\
\hline
\end{tabular}

Source: LOT Annual Reports 2005-2008, ULC data, own calculations.

Data presented above shows that number of passengers served by LOT Polish Airlines increased slightly between years 2004 and 2007 to more than 5,4 millions of customers and decreased to almost 5 millions of passengers in year 2008. LOT was loosing its market share in the Polish market, which was falling continuously from almost $58 \%$ in year 2004 to only $28 \%$ in 2008 , as a result of rapid expansion of low cost airlines and lower price competitiveness of flag carriers in comparison with such new suppliers of passenger air transport service.

Low cost airlines gained a strong position on the Polish market during presence of the country in the European Union. Their market share increased continuously from $13 \%$ in year 2004 to more than $52 \%$ in year 2008 . Liberalisation of air transport enabled low cost airlines to gain more than half of the passenger air transport market in Poland within five years. Low cost airlines contributed to development of regional airports in Poland and to increase of traffic in general, generated majority of the growth. 
Table 4. Number of passengers served at the polish airports in years $2004-2008$ (in thousand of passengers)

\begin{tabular}{|l|c|c|c|c|c|}
\hline \multicolumn{1}{|c|}{ Airport $\backslash$ Year } & $\mathbf{2 0 0 4}$ & $\mathbf{2 0 0 5}$ & $\mathbf{2 0 0 6}$ & $\mathbf{2 0 0 7}$ & $\mathbf{2 0 0 8}$ \\
\hline Warszawa-Okęcie & 6085,1 & 7071,7 & 8101,8 & 9268,5 & 9437,0 \\
\hline Kraków-Balice & 841,1 & 1564,3 & 2367,5 & 3042,4 & 2895,3 \\
\hline Katowice-Pyrzowice & 622,6 & 1083,5 & 1458,4 & 1962,6 & 2406,6 \\
\hline Gdańsk-Rębiechowo & 464,7 & 677,9 & 1249,8 & 1708,7 & 1951,1 \\
\hline Wrocław-Strachowice & 363,2 & 454,0 & 865,9 & 1267,6 & 1480,5 \\
\hline Poznań-Ławica & 380,7 & 399,2 & 670,7 & 863,0 & 1255,9 \\
\hline Rzeszów-Jasionka & 71,9 & 91,5 & 206,9 & 274,3 & 321,0 \\
\hline Szczecin-Goleniów & 95,8 & 100,8 & 176,7 & 228,1 & 298,6 \\
\hline Łódź-Lublinek & 6,3 & 18,1 & 216,8 & 312,2 & 341,8 \\
\hline Bydgoszcz-Szwederowo & 26,1 & 38,7 & 133,0 & 182,4 & 264,9 \\
\hline Zielona Góra-Babimost & 4,3 & 0,4 & 8,3 & 6,7 & 5,2 \\
\hline Total & $\mathbf{8 9 6 1 , 8}$ & $\mathbf{1 1} \mathbf{5 0 1 , 2}$ & $\mathbf{1 5 4 5 5 , 8}$ & $\mathbf{1 9} \mathbf{1 1 6 , 5}$ & $\mathbf{2 0} \mathbf{6 5 7 , 8}$ \\
\hline Yearly growth & $25,9 \%$ & $28,3 \%$ & $34,4 \%$ & $23,7 \%$ & $8,1 \%$ \\
\hline
\end{tabular}

Source: ULC data, own calculations.

Yearly traffic at Polish airports began to rise rapidly after accession to the European Union. In year 2004 number of passengers served at Polish airports increased in comparison with the previous year by almost $26 \%$. It was a beginning of a long trend of significant growth between year 2004 and 2007, recorded more than $34 \%$ growth in year 2006 . The total number of passengers at all polish airports between year 2004 and 2008 increased by $130 \%$ from almost 9 millions in 2004 to more than 20 millions in year 2008. However, dynamics of traffic growth in Poland in year 2008 slowed down to only $8 \%$.

The highest percentage growth between years 2004 and 2008 recorded airport in Lodz, where traffic increased by $5325 \%$ and Bydgoszcz with $915 \%$ growth. All other regional airports in Poland noted more than $200 \%$ growth in the mentioned period. Only Zielona Gora is out of the significance in the statistics. Airports such as Krakow, Katowice, Gdansk, Wroclaw and Poznan play a very important role, reaching more than $48 \%$ of a market share in year 2008. The five above mentioned airports together with Warsaw Okecie noted 94\% market share in 2008 in comparison with almost 98\% in year 2004 . 
Table 5. Number of passengers served at Warsaw-Okęcie airport in years $2003-2008$

\begin{tabular}{|l|c|c|c|c|c|c|}
\hline Year & $\mathbf{2 0 0 3}$ & $\mathbf{2 0 0 4}$ & $\mathbf{2 0 0 5}$ & $\mathbf{2 0 0 6}$ & $\mathbf{2 0 0 7}$ & $\mathbf{2 0 0 8}$ \\
\hline $\begin{array}{l}\text { Number of passengers } \\
\text { (in thousand) }\end{array}$ & 5167,0 & 6085,1 & 7071,9 & 8101,8 & 9268,6 & 9437,0 \\
\hline Year by year change & $4,7 \%$ & $17,8 \%$ & $16,2 \%$ & $14,6 \%$ & $14,4 \%$ & $1,8 \%$ \\
\hline Polish market share & $72,6 \%$ & $67,9 \%$ & $61,5 \%$ & $52,4 \%$ & $48,5 \%$ & $45,7 \%$ \\
\hline
\end{tabular}

Source: ULC data, own calculations.

Warsaw Okecie airport is loosing market share constantly, from more than $70 \%$ before Polish accession to the European Union to about 45\% in year 2008. On the other hand regional airports are improving their situation year by year, as far as market share is concerned. Such a tendency can be continuous, taking into consideration dynamic development of low cost airline services at regional airports. Moreover, it can be assumed that the hub airport in Warsaw is loosing its potential to dynamic growth, facing more intensively a problem of congestion.

\section{Conclusion}

Not knowing what would have happened in the absence of liberalisation makes it difficult to assess the impact of the single aviation market in Europe with any precision. But the new regulatory environment certainly has fostered innovation and enterprise, resulting in more routes served and greater competition on many existing routes. The emergence of no-frills carriers, which would have been impossible before the liberalisation, has changed the way many people think about air transport, and has necessitated a competitive response from their longer-standing rivals. Consumers have benefited not only from a wider range of choice, both in locations served and in quality and type of service, but also from lower prices.

Poland has strongly benefited from air transport liberalisation and became one of the most rapidly developing civil aviation markets in the world. The high rates of low cost carriers passenger traffic growth in Poland were a result of a high market potential for air transport services. The sector was underdeveloped due to a lack of competition resulting in high fares. Low cost carriers increased air mobility of the polish society and created new demand for this mode of 
transport. This could be observed particularly in the regional airports, which recorded dynamic growth in number of passengers due to the new suppliers entrance. Economic crisis can contribute to the slower than expected development but still Poland will remain in the group of countries with the highest expected passenger number growth rate.

\section{References}

Button K. (2001), Deregulation and Liberalization of European Air Transport Markets, Innovation: The European Journal of Social Sciences, Volume 14, no 3

Dennis N. (2001), The Impact of Airline Deregulation, [in:] R. Tolley, B.Turton (ed.), Global Transport Issues, Tauris Publishers, London

Dziedzic T. (2005), Rynek lotniczy w Polsce. Stan obecny i perspektywy, Instytut Turystyki, Warszawa

http://ec.europa.eu/transport/air/index_en.htm

http://ec.europa.eu/transport/air/internal_market/integration_history_en.htm

European Commission (2005), Annual Energy and Transport Review, Directorate-General for Energy and Transport, Office for Official Publications of the European Communities, Luxembourg

European Commission (2007), Information Society and Transport: Linking European Policies, Office for Official Publications of the European Communities, Luxembourg

European Commission (2007), Guide to European Community Legislation in the Field of Civil Aviation, Directorate-General for Energy and Transport, Office for Official Publications of the European Communities, Luxembourg

European Commission (2004), The Single European Sky. Implementing Political Commitments, Directorate-General for Energy and Transport, Office for Official Publications of the European Communities, Luxembourg

European Council (1992), Regulation No 2407/92 on Licensing of Air Carriers

European Council (1992), Regulation No 2408/92 on Access to Air Routes

European Council (1992), Regulation No 2409/92 on Fares and Rates for Air Services

Gamba F. (2008), Recent EU Implementations on Air Traffic Services. AEA Perspective, www.aea.com

Grzywacz W., Rydzkowski W., Wojewódzka-Król K. (2003), Polityka transportowa, Wydawnictwo Uniwersytetu Gdańskiego, Gdańsk

IATA (2004), IATA Passenger Forecast 2005-2009, www.iata.org 
ICAO (2003), European Experience of Air Transport Liberalization, www.icao.org

Jastrzębska J., Liberalizacja transportu lotniczego UE w perspektywie funkcjonowania na rynku globalnym (cz.1), Logistyka, 1999, no 6

Jastrzębska J., Liberalizacja transportu lotniczego UE w perspektywie funkcjonowania na rynku globalnym (cz.2), Logistyka, 2000, no 1

Liwiński J. (2009), Działalność polskich portów lotniczych 2004 - 2008, Ośrodek Informacji Naukowej Technicznej i Ekonomicznej, ULC, Warszawa 2009

Liwiński J. (2009), Działalność polskich przewoźników 2004-2008, Ośrodek Informacji Naukowej Technicznej i Ekonomicznej, ULC, Warszawa 2009

www.lot.pl

Marszałek A. (2005), Integracja europejska, PWE, Warszawa

Page S.J. (2005), Transport and Tourism, Person Prentice Hall, Harlow

Paprocki W., Pieriegud J. (2005), Wpływ procesów demonopolizacji I konsolidacji w transporcie na sprawność i efektywność jego funkcjonowania, SGH, Warszawa

Polkowska M.(2004), Zasady tworzenia jednolitego europejskiego rynku usług lotniczych, 'Studia Europejskie', Centrum Europejskie Uniwersytetu Warszawskiego, Warszawa, no 4

Rocka K., Weyna M. (2006), Development of LCC in Poland after EU Accession, SGH, Warsaw

Sinha D. (2002), Deregulation and Liberalisation of the Airline Industry, Ashgate Publishing Limited, Aldershot

Szymajda I. (2002), Prawo lotnicze Unii Europejskiej - charakterystyka systemu, 'Studia Europejskie', Centrum Europejskie Uniwersytetu Warszawskiego, Warszawa, no 1

Travis R. (2001), Air Transport Liberalisation in the European Community 1987-1992. A Case of Integration, Uppsala University Press, Uppsala

Treaty of European Union, 1992

Treaty of Rome, Consolidated Version of the Treaty Establishing the European Community, Official Journal of the European Communities:

http://eur-lex.europa.eu/en/treaties/dat/12002E/pdf/12002E_EN.pdf

Teluk T. (2004), Podniebna konkurencja, Boss Gospodarka, 2004, no 8

www.ulc.gov.pl (Polish Aviation Council) 